\title{
Problemy oświaty i edukacji w 1882 r. w kontekście tarnowskiego pisma ekonomiczno-społecznego „Orzel”
}

Dwutygodnik „Orzeł” ukazywał się w Tarnowie w latach 1882-18831, jego wydawcą i założycielem był Jan Karol Włodarski. Czasopismo wydawano w drukarniach Anastazego Rusinowskiego, Józefa Styrny, Fischera i Dutschera w Krakowie $^{2}$, a nakład liczył 500 egzemplarzy ${ }^{3}$. Publikowane przez J. K. Włodarskiego jednodniówki „Puchacz” (15 sierpnia 1884 r. $^{4}$ ) i „Sokół Tarnowski” (10 stycznia $1885 \mathrm{r}^{5}$ ) stanowiły próby wznowienia pisma.

"Orzeł" miał charakter ekonomiczno-społeczny, ukazywał się 1. i 15. dnia każdego miesiąca. Istniały w nim stałe rubryki, takie jak m.in. "Sprawy gminne i powiatowe”, „Kronika miejscowa i zamiejscowa”, „Stowarzyszenia”, „To i owo”, „Nadesłane”, „Spóźnione”, „Zapiski bibliograficzne”, „Pytania i odpowiedzi”, „Nowości”, „Rozmaitości”, „Korespondencje”, zamieszczano także powieść w odcinkach, poezje, humoreski.

Wydawcy nie zakładali realizowania celów edukacyjnych, a jednak dokładnie

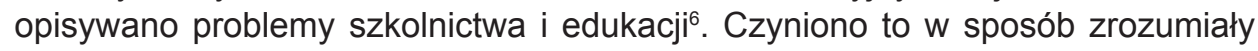
dla szerokiego grona odbiorców. W zależności od przedstawianych zagadnień zamieszczano w periodyku różnorodne teksty prasowe - niekiedy były to tylko wzmianki, a w innych przypadkach dłuższe artykuły. Omawiano zagadnienia

* Dr, Zakład Administracji Publicznej, Instytut Administracyjno-Ekonomiczny, Państwowa Wyższa Szkoła Zawodowa w Tarnowie, ul. Mickiewicza 8, 33-100 Tarnów.

1 S. P o tę p a, Życie kulturalne w okresie autonomii galicyjskiej, [w:] Tarnów. Dzieje miasta i regionu, t. 2: Czasy rozbiorów i drugiej Rzeczypospolitej, red. F. Kiryk, Z. Ruta, Tarnów 1983, s. 377-380; E. J a s i e w i c z - K a r g ó I, „Orzel”, [w:] Encyklopedia Tarnowa, red. A. Niedojadła, Tarnów 2010, s. 290-291.

2 E. Ja si ewicz-Kargól, „Orzef”, s. 290.

${ }^{3}$ S. P o tę p a, Życie kulturalne, s. 377-380; E. J a s i e w i c z-K a r g ó l, „Orzef”, s. 290.

${ }^{4}$ E. Jasiewicz-Kargól, „Orzef”, s. 291.

5 Tamże.

${ }^{6}$ Archiwum Diecezjalne w Tarnowie, Akta szkolne, Sprawozdanie c. k. Rady Szkolnej o stanie wychowania publicznego w roku szkolnym 1881/1882 i 1882/18883. Szkoły ludowe i Seminaria nauczycielskie, Lwów 1884. 
związane z edukacją i szkolnictwem różnych szczebli w mieście, regionie czy nawet w świecie, publikowano również komentarze i pytania otwarte.

Moje rozważania obejmują analizę tekstów prasowych zamieszczonych w „Orle” w 1882 r., czyli w okresie bardzo istotnym dla tarnowskiej oświaty, kiedy to $w$ mieście powołano m.in. Towarzystwo Oświaty Ludowej (TOL) ${ }^{7}$. Wydarzenia z kręgu edukacji i szkolnictwa, ważne przede wszystkim dla miasta i regionu, które ujęto i komentowano w piśmie "Orzel” na przestrzeni 1882 r. okazały się niezwykle ciekawe i różnorodne. Zgodnie z przyjętą w piśmie zasadą, najpierw dane wydarzenie zapowiadano, najczęściej w formie wzmianki w numerze wcześniejszym, a w następnym - opisywano nieco szerzej i komentowano. Należy jednak zaznaczyć, że na łamach tarnowskiego „Orła” omawiano przede wszystkim zagadnienia ekonomiczno-społeczne, co było zgodne z profilem pisma.

Analizę publikacji zamieszczonych w „Orle” w 1882 r. należy rozpocząć od tekstów poświęconych powołaniu tarnowskiego TOL. Artykuł informujący o jego powstaniu ukazał się w czerwcu 1882 r. na łamach „Pogoni”. Ze względu na fakt, że w opublikowanym tekście „wiele rzeczy przekręcono”, do redakcji „Orła” nadsyłano liczne sprostowania i dlatego w piśmie zamieszczono obszerne i szczegółowe sprawozdanie autorstwa Franciszka Stołobota i Franciszka Winkowskiego z przebiegu spotkania, w trakcie którego powołano Towarzystwo. Autorzy publikacji dokładnie opisywali przebieg wydarzeń, zwracając uwagę, że dopiero w niedzielę 7 maja 1882 r. w godzinach porannych na ulicach miasta rozlepiono afisze informujące, iż tego samego dnia po południu, o godzinie 15.00 , odbędzie się pod przewodnictwem dyrekcji „Gwiazdy Tarnowskiej”"10 spotkanie, podczas którego powstanie $\mathrm{TOL}^{11}$. Społeczność lokalną dziwił fakt, że o tak ważnym fakcie informowano zbyt późno, w pośpiechu, uniemożliwiając osobom spoza Tarnowa wzięcie udziału w tym posiedzeniu. Przebieg zebrania rozczarował uczestników, „nie chodziło o założenie towarzystwa oświaty takiego, jakie powstało w rozlicz-

7 B. J a ś k i e w i c z, Działalność towarzystw oświatowych w Tarnowie w latach autonomii galicyjskiej, „Rozprawy z Dziejów Oświaty” 1974, t. XVII, s. 116-117.

8 To najpierw dwutygodnik (1881-1887), a potem tygodnik (1888-1914) polityczno-społeczny, wydawany przez Józefa Pisza w Tarnowie.

9 "Orzeł” [Tarnów], 1 VI 1882, nr 1, s. 7.

10 Stowarzyszenie Rękodzielników Chrześcijańskich „Gwiazda Tarnowska” zostało utworzone w 1881 r. (po przekształceniu Stowarzyszenia Rękodzielników „Gwiazda Tarnowska” powstałego w 1869 r.). Głównym zadaniem organizacji kierowanej przez ks. Adama Kopycińskiego było m.in. szerzenie oświaty wśród rzemieślników, popieranie i obrona ich interesów, pomoc materialna potrzebującym członkom. S. P i e ch, Stowarzyszenie Rękodzielników Chrześcijańskich „Gwiazda Tarnowska”, [w:] Encyklopedia Tarnowa, s. 410; Trzydziestolecie „Gwiazdy Tarnowskiej", od 6 listopada 1881 do 6 listopada 1911, Tarnów 1912, passim; B. J a ś k i e w i c z, Rzemieślnicze stowarzyszenia społeczno-kulturalne w Tarnowie (1860-1918), „Studia Historyczne” 1975 , z. 3, s. 323-337.

11 W ramach TOL w Tarnowie (od 1899 r. współpracowało z krakowskim oddziałem) utworzono bibliotekę, organizowano także różnorodne odczyty poświęcone zagadnieniom historycznym, literackim, społecznym, ekonomicznym, politycznym, religijnym. Od 1907 r. w Tarnowie funkcjonowało 11 czytelni TOL. Oddział tarnowski obejmował swoim zasięgiem mniejsze miejscowości w powiatach: tarnowskim, dąbrowskim, pilzneńskim, brzeskim. Koło tarnowskie połączyło się z kołem krakowskim w 1910 r. 
nych innych miastach Galicji, lecz o zawiązanie ciasnego kółka wzajemnego pouczania się”"12. „Gwiazda”, chcąc przysłużyć się sprawie publicznej, pozwalała nowemu Towarzystwu korzystać ze swojej sali oraz z księgozbioru, w pozostałych sprawach pozostawiała mu swobodę działania „w urządzeniu i rozwijaniu się, nie żądając w zamian niczego więcej prócz tego chyba, aby jej członkowie mogli mieć bezpłatny udział w towarzystwie oświaty” ${ }^{3}$. Członkowie „Gwiazdy” przybyli na zebranie $z$ gotowym projektem statutu, a na zgłaszane propozycje zebranych nie reagowali. Podczas czytania tekstu, kiedy sugerowano pewne zmiany, niechętnie brano je pod uwagę. Głos w tej sprawie zabrał Mikołaj Jamrowicz: „Eh, co tam będziemy słuchać, jakeśmy [...] w stowarzyszeniu uchwalili, to tak głosujmy"14. Z kolei prezes „Gwiazdy”, ks. dr Adam Kopyciński, odniósł się do przyczyn, jakie skłoniły Towarzystwo Rękodzielników do utworzenia Towarzystwa Oświaty, wskazując nie tylko na tzw. „wspólność celu”"15, konieczność szerzenia oświaty wśród zrzeszonych w Towarzystwie, lecz także na obowiązek upowszechniania jej przez inteligencję wśród przedstawicieli wszystkich stanów. W odpowiedzi na to przemówienie zaczęto zadawać liczne pytania dotyczące postawy inteligencji oraz formułować zarzuty, że nie troszczy się ona o oświatę, ponieważ nawet na to spotkanie przyszli tylko nieliczni jej reprezentanci. W obronie inteligencji wystąpił wówczas prof. Roman Wimpeller, twierdząc, że nie mogła ona przybyć, ponieważ dopiero poprzedniego dnia późnym wieczorem dowiedziała się o spotkaniu.

Następnie odczytano poszczególne punkty statutu. Już w tytule, na wniosek Franciszka Winkowskiego ${ }^{16}$, wprowadzono dwie poprawki: w miejsce przedłożonego przez „Dyrekcję Gwiazdy a brzmiącego: Towarzystwo Oświaty dla miasta Tarnowa - uchwalono nowy: Towarzystwo Oświaty Ludowej dla miasta Tarnowa i okolicy"17. Statut określał różne formy działania, niewymagające większych środków finansowych, a mające służyć szerzeniu oświaty, takie jak czytanie gazet i książek, organizowanie odczytów. W tej sprawie głos zabrał F. Winkowski sugerując, aby paragraf ten zmienić według statutu Iwowskiego stowarzyszenia, które zastrzegło sobie większe środki. „Wniosek ten upadł wskutek przekonywującej przemowy p. Jamrowicza koncentrującej się w tych słowach: «Co nam do Iwowskiego towarzystwa, ono inne, nasze inne, my tu mamy swoje, więc głosujmy, jakeśmy w ‘Gwiaździe' uchwalili»”18.

Gwałtowną dyskusję wywołał kolejny punkt statutu zawierający stwierdzenie, że członkiem TOL może być tylko osoba wyznania katolickiego. Pierwszy sprzeciwił się temu R. Wimpeller, „wyrażając uzasadnione zadziwienie, dlaczego żyd

12 „Orzeł” [Tarnów], 1 VI 1882, nr 1, s. 7.

13 Tamże.

14 Tamże.

15 Tamże.

${ }^{16}$ Franciszek Winkowski (1858-1903), nauczyciel gimnazjalny; po ukończeniu studiów na Wydziale Prawa UJ prowadził kancelarię adwokacką w Tarnowie; w latach 1897-1900 poseł z okręgu tarnowskiego do austriackiej Rady Państwa. Słownik biograficzny działaczy ruchu ludowego, Warszawa 1989, s. 428.

17 „Orzeł" [Tarnów], 1 VI 1882, nr 1, s. 7.

18 Tamże. 
czy protestant nie może popierać oświaty lub z oświaty korzystać"19. Tego samego zdania był F. Winkowski, który wykazywał, że „przez usunięcie tego ustępu uniknie się niepotrzebnych rozdrażnień i nie narazi się towarzystwa na żadne złe następstwa"20. Inne stanowisko wyrażał np. dr Aleksander Pechnik twierdząc, że „żydzi po to tylko przystąpią do stowarzyszenia, aby wyśmiewać naszą wiarę i wprowadzać demoralizację”21. Ostatecznie jednak postanowiono „wszystkich innowierców od towarzystwa wyłączyć, co wielu obecnych rozsądnych ludzi zraziło zupełnie i uczyniło obojętnymi. [...] Sprawa oświaty nie jest sprawą wyznania, lecz sprawą narodu, naród zaś pragnie, by wszyscy jego obywatele bez różnicy stali się oświeconymi, by przez naukę stali się uczciwymi ludźmi i dzielnymi synami kraju"22.

Kolejne punkty statutu wywoływały jeszcze większe emocje, a zwłaszcza ten dotyczący wyboru władz. Postanowiono, że TOL nie będzie wybierać swego Wydziału, a pozostanie pod zarządem Dyrekcji „Gwiazdy”. Przeciwko temu wystąpił F. Winkowski, który żądał osobno wybieranego Wydziału i podkreślał, że prawo wyboru było „najdroższym przywilejem członków każdego dobrowolnego stowarzyszenia i nikt nie zechce należeć do towarzystwa, w którym rządzi ktoś narzucony z góry na kierownika, a nie wybrany przez członków"23. Zwracał uwagę, że w każdym towarzystwie decydują o tym jego członkowie. Stwierdził, że do TOL mogą należeć nie tylko rzemieślnicy i pytał, dlaczego więc oni mają głos decydujący. Dyrekcja „Gwiazdy” obejmowała Kuratorię (w niej zasiadali gruntownie wykształceni obywatele) i Wydział (ten gromadził osoby wybrane ze względu na swą fachową wiedzę, nie mogące mieć pretensji do kierowania oświatą w mieście i okolicy). R. Wimpeller zgłosił pośredni wniosek, aby Wydział był wybieralny, a Dyrekcja „Gwiazdy” należała do niego z obowiązku. Wniosek ten po rozważeniu przyjęto i zakończono dalsze czytanie statutu. Prace nad nim powierzono specjalnej Komisji w składzie: A. Pechnik, Z. Morawski, S. Matwij, F. Winkowski24, która miała się zająć stylistycznym opracowaniem tekstu ${ }^{25}$. Do tego zagadnienia powracano w 2. numerze „Orła” wyjaśniając, że temat ten podjęto z chęci „bronienia oświaty przed niepożądanymi zapędami Dyrekcji «Gwiazdy»"26.

Kolejne informacje dotyczące TOL pojawiły się w „Orle” w związku ze zwołaniem w niedzielę 22 października 1882 r. pierwszego walnego zgromadzenia Towarzystwa. Wzięło w nim udział około 130 osób, przede wszystkim nauczycieli i rzemieślników, z których 85 posiadało prawo głosu. Posiedzenie rozpoczęła przemowa ks. dr. A. Kopycińskiego ${ }^{27}$, w której stwierdził, że „rząd nie spoczywa

\footnotetext{
19 Tamże.

20 Tamże.

21 Tamże.

22 Tamże, s. 7-8.

23 Tamże, s. 8.

${ }^{24}$ F. Winkowski zgłaszał, że nie zgadza się ze statutem.

25 Tamże.

26 „Orzeł” [Tarnów], 15 VI 1882, nr 2, s. 1-2.

27 Publikowaną przez „Orła” wraz z komentarzem redakcyjnym. „Orzeł” [Tarnów], 1 XI 1882,
} nr 11, s. 5 . 
w ręku jednego człowieka lub kilku magnatów, lecz w ręku ogółu”28 i wyróżniał różne gatunki oświaty. Według redaktorów „Orła”, „oświata jest tylko jedna, a zaś uczucia mogą być rozmaite, oświata nie jest uczuciem, a więc nie można wyróżniać kilka rodzajów oświaty mianowicie: katolicką, akatolicką, kosmopolityczną, narodową itp." 29 . W trakcie tego posiedzenia przystąpiono do głosowania nad składem Wydziału i wybrano następujące osoby: Romana Wimpellera, Spirydiona Makarewicza, dr Aleksandra Pechnika, Franciszka Haburę i ks. Franciszka Krystę.

Na początku lipca 1882 r. „Orzeł” przekazał wiadomość, że również w Krakowie powołano Towarzystwo Oświaty Ludowej. Jego władze stanowili: jako przewodniczący dr F. Weigel, sekretarz dr W. Dadlec, natomiast członkami zostali: W. Anczyc, dr A. Asnyk, K. Bartoszewicz, dr F. Czesnak, A. Getlich, W. Jabłoński, J. Maciałowski, T. Romanowicz, E. Schwarz, S. Zarański, I. Żółtowski. Do obywateli skierowano odezwę, w której przekazano, że członkami TOL mogą zostać wszyscy chętni, bez różnicy wieku, płci, wyznania, zatrudnienia, pozycji majątkowej ${ }^{30}$.

Na łamach „Orła” informowano o zbliżającym się walnym zgromadzeniu tarnowskiego Oddziału Towarzystwa Pedagogicznego. Zarząd Towarzystwa w taki sposób zapraszał swoich członków na spotkanie, które zapowiedziano na dzień 11 czerwca 1882 r. o godzinie $15.00 \mathrm{w}$ szkole w Tuchowie. W trakcie obrad przewidywano rozpatrzenie sześciu punktów: odczytanie protokołu z ostatniego posiedzenia; sprawozdanie z czynności wydziału; odczyt p. prof. Zygmunta Morawskiego O pierwszych ustrojach ziemi; wybór delegata na walny zjazd do Kołomyi; odczyt prof. Ignacego Przybyłkiewicza Komety, straszne ich skutki w razie zetknięcia się ze ziemią i obalenie przesądów i zabobonów ludowych, odnoszących się do komet; wnioski członków ${ }^{31}$. Okazało się jednak, że w zwołanym walnym zgromadzeniu wzięła udział niewielka liczba członków, niektóre tarnowskie szkoły nie były reprezentowane, ponieważ nauczyciele nie przybyli do Tuchowa. „Orzeł" przypominał więc, że wpisując się do Towarzystwa Pedagogicznego bierze się na siebie pewne obowiązki obywatelskie.

$\mathrm{Na}$ łamach pisma przedstawiono szczegółową relację z tego wydarzenia. W sali ratusza członków Towarzystwa w imieniu miejscowej rady szkolnej i duchowieństwa powitał ks. kanonik Jan Rybarski, następnie przewodniczący prof. R. Wimpeller scharakteryzował dotychczasową działalność Towarzystwa Pedagogicznego, wyliczając jego zasługi. Po odczytaniu protokołu i odezw centralnego zarządu, referat wygłosił Zygmunt Morawski ${ }^{32}$. Potem dokonano wyboru delegata na zgromadzenie mające się odbyć w Kołomyi (został nim prof. Aleksander Pechnik). Z kolei nauczyciela Józefa Bereczkowskiego wybrano na tymczasowego sekretarza tarnowskiego kółka pedagogicznego, ponieważ dotychczasowy sekretarz Jan Ciejka ustąpił z powodu przeniesienia do Wiśnicza.

\footnotetext{
28 Tamże.

29 Tamże.

30 "Orzeł” [Tarnów], 1 VII 1882, nr 3, s. 3.

31 Przekazano również szczegółowe informacje odnośnie do godzin wyjazdu i przyjazdu pociągu do Tuchowa. Pociąg odjeżdżał z Tarnowa po południu, o godz. 13.40, wracał - dokładnie o 23.00.

32 Tamże, s. 9.
} 
Jednak, według najnowszych informacji, zmienił zdanie i pozostał w Tarnowie, tym samym nadal mógł pracować dla TP. W dalszej części spotkania prof. A. Pechnik odczytał przygotowany projekt memoriału w sprawie reformy szkół średnich, przedłożony walnemu zgromadzeniu, a następnie po opracowaniu wniesiony do Rady Szkolnej Krajowej Sejmu i Koła Polskiego w Wiedniu. „Orzeł” opisywał także życzliwe przyjęcie gości przez władze miasta Tuchowa i grono nauczycielskie ${ }^{33}$.

W tarnowskim „Orle” znalazła się informacja przekazana przez Zarząd Oddziałowy TP, który zawiadamiał członków o XVI walnym zgromadzeniu ${ }^{34}$, planowanym na 17-19 lipca w Kołomyi. Zgodnie z programem, jaki zamieszczono w 18. numerze „Szkoły” z 1882 r., członkowie Towarzystwa, chcący wziąć w nim udział, powinni zgłosić się po kartę uczestnictwa do zarządu oddziałowego i wpłacić 1,50 zł (kartę należało przesłać na ręce sekretarza najpóźniej do 25 czerwca $1882 r^{35}{ }^{35}$. W piśmie drukowano też teksty prasowe odnoszące się do różnych wydarzeń, mających miejsce w tarnowskich szkołach.

Na początku czerwca 1882 r. młodzież tarnowskich szkół handlowych ${ }^{36}$, wraz ze swymi opiekunami, przygotowywała się do zorganizowania 11 dnia tego miesiąca majówki na górze św. Marcina. Planowano zaprosić na nią ponad 500 osób, ponieważ miała przewyższać świetnością wszystkie organizowane dotychczas, w programie znalazły się tańce, zabawy, gry towarzyskie. W komitecie organizacyjnym pracowali Kamil Baum ${ }^{37}$, Jan Kadernożka i Jan Krempo ${ }^{38}$. W szczegółowej relacji $z$ tego wydarzenia ${ }^{39}$ podkreślano, że majówka należała do udanych nie tylko z powodu dobrej pogody, lecz przede wszystkim ze względu na dobrą organizację („porządek wzorowy, a bufet dobrze zaopatrzony”40), właściwy wybór miejsca - kotliny u podnóża góry św. Marcina. Rozpoczynała się ok. godziny 15.00, uczestniczyło w niej ponad tysiąc osób, m.in. książę Sanguszko, burmistrz miasta, wiele wybitnych osobistości cywilnych i wojskowych ${ }^{41}$. Zorganizowano loterię fantową, z której dochód przeznaczono na cele, których jeszcze nie określono ${ }^{42}$.

W „Orle" informowano również o egzaminach i popisach w tarnowskich szkołach: w szkole przemysłowo-handlowej 4 czerwca 1882 r. o godzinie 15.00 (pod przewodnictwem księcia starosty Ponińskiego, delegata Wydziału Krajowego Ludwika Wierzbickiego, zastępcy dyrektora ruchu kolei czerniowieckiej dyrektora Bronisława Trzaskowskiego, dr Karola Kaczkowskiego, burmistrza Aleksandra Wisłockiego, dyrektora Jana Szubowicza oraz obywateli rzemieślników $\left.{ }^{43}\right)$ i w męskiej szkole wydziałowej w dniach od 26 do 30 czerwca 1882 r. (pod przewodnic-

33 Tamże, s. 10.

${ }^{34}$ W myśl okólnika Zarządu Głównego z dnia 7 maja 1882 r.

35 Tamże, s. 9.

36 "Orzeł” [Tarnów], 1 VI 1882, nr 1, s. 5.

37 Był kupcem i wydawcą widokówek Tarnowa.

38 Tamże.

39 „Orzeł” [Tarnów], 15 VI 1882, nr 2, s. 4.

40 Tamże.

41 Tamże.

42 „Orzeł” podawał do wiadomości, jeśli tylko były uchwalone.

43 Jak skomentowano w „Orle”, mimo zaproszenia skierowanego do rękodzielników, tylko niewielka ich grupa przybyła. 
twem inspektora Franciszka Habury ${ }^{44}$ ). Zamieszczano porządek zapowiadanych popisów, wymieniając kolejno szkoły biorące w nich udział, czyli szkołę etatową żeńską, szkołę etatową męską, szkołę wydziałową żeńską.

Czytelnicy „Orła” mogli dowiedzieć się o przeprowadzanych egzaminach dojrzałości w tarnowskich szkołach, np. w gimnazjum odbywał się ustny egzamin dojrzałości pod przewodnictwem ks. Bazylego Ilnickiego, zastępcy inspektora krajowego, który cztery osoby zdały z wyróżnieniem ${ }^{45}$.

Redakcja zamieszczała artykuły o charakterze żartobliwym. Kiedy w „Unii”46 (w dziale „Zapiski bibliograficzne”) opublikowano tekst informujący o tym, że „Franciszek Wężyk już przełożył na język polski Edypa króla Sofoklesa i Eneidę Wergilego, tudzież, że Paweł Popiel przełożył wierszem miarowym Iliadę Homera"47, w „Orle” pojawił się ironiczny komentarz:

Czekamy, rychło ów sprawozdawca z ruchu literackiego doniesie, że Adam Mickiewicz już napisał Pana Tadeusza i że Słowacki zabiera się do napisania np. Balladyny. [...] Franciszek Wężyk umarł w 1862 r., więc już od dawna nic nie przekłada, tylko się jego przekłady drukuje, i że Iliada Pawła Popiela jeszcze przed 3ma laty wyszła z druku, a obecnie drugi nakład ukazał się w handlu ${ }^{48}$.

W „Orle” publikowano doniosłe wiadomości, odnoszące się do edukacji szeroko rozumianego regionu. W związku z największą od 200 lat liczbą studentów zapisanych na Uniwersytet Wiedeński, zamieszczano dokładne statystyki, ilu chętnych i na jakich wydziałach rozpocznie studia w 516 roku istnienia tej uczelni. W roku akademickim 1881/1882 studia zaczynało 4823 słuchaczy ${ }^{49}$, najwięcej na wszystkich uniwersytetach Austrii i Niemiec. Zamieszczano dokładne dane liczbowe w odniesieniu do poszczególnych wydziałów. Studia na Wydziale Teologicznym podjęło 226 słuchaczy, na prawniczym 2240, na medycznym 1412 (oraz 176 farmaceutów), na filozoficznym 709. Najwięcej studentów wybrało Wydział Medyczny, gdyż liczba ich od roku akademickiego 1877/1878 wzrosła z 712 do 1412, a więc prawie się podwoiła. Studenci pochodzili ze wszystkich krajów monarchii. Z Polski było ich 418, z Moraw - 507, z Czech - 503, a 988 z krajów zalitawskich, a ponadto 35 z Niemiec, 6 ze Szwajcarii, 4 z Francji, 1 z Belgii, 22 z Włoch, 1 ze Szwecji, 6 z Anglii, 35 z Rosji, 5 z Bułgarii, 11 z Turcji, 1 z Czarnogóry, 65 z Rumunii, 29 z Serbii, 3 z Grecji, 3 z Azji, 1 z Afryki i 13 z Ameryki50.

W „Orle” zamieszczano teksty, w których dokładnie opisywano postępy w nauce tarnowskiej młodzieży. Przedstawiciele redakcji pisma, przyglądając się m.in.

44 Tamże, s. 3-4.

45 Tamże, s. 11.

${ }^{46}$ Dwutygodnik wydawany w Tarnowie od 4 VI 1882 do 30 VI 1888 r., na przemian z dwutygodnikiem „Pogoń”. Wydawcą tych czasopism był Józef Pisz, a jego brat, księgarz Karol Pisz - nominalnym redaktorem naczelnym. W rzeczywistości duży wpływ na charakter pism wywierali ks. dr Adam Kopyciński, dr Aleksander Pechnik i dr Karol Kaczkowski. W 1888 r. J. Pisz zaprzestał wydawania „Unii”, przekształcając jednocześnie „Pogoń” w tygodnik; pismo ukazywało się do 1914 r.

47 „Orzeł” [Tarnów], 15 VI 1882, nr 2, s. 11.

48 Tamże.

49 W semestrze zimowym roku 1880/1881 liczyła 4572 osób. Tamże, s. 7.

50 Tamże. 
przebiegowi ${ }^{51}$ odbywających się w dniach 26 i 27 czerwca 1882 r. egzaminów w czteroklasowej męskiej szkole, zwracali uwagę na dobre relacje panujące między uczniami a nauczycielami, ponadto na duże zaangażowanie w pracę nauczycieli ${ }^{52}$. W piśmie wydrukowano pełny tekst pożegnania, jakie wygłosiła Maria Warmska, uczennica VIII klasy ${ }^{53}$.

W „Orle” znalazła się również relacja z popisu w szkole więziennej sądu obwodowego, który odbył w niedzielę 9 lipca 1882 r. Do specjalnie przygotowanej sali, w której znajdowało się popiersie i obraz Cesarza, najpierw przybyli zaproszeni goście ${ }^{54}$, a potem różniący się wiekiem uczniowie $\mathrm{w}$ więziennych ubraniach ${ }^{55}$. Popisowi przewodniczył Franciszek Habura, inspektor okręgowy, a ze strony księdza biskupa delegat ks. Radwański. Szkoła podzielona była na dwa oddziały. Po zakończeniu popisu z przedmiotów: czytanie poglądowe, rachunki, geografia, historia kraju rodzinnego miała miejsce klasyfikacja, kilku uczniów otrzymało nagrody - książki do nabożeństwa. Następnie głos zabrał F. Habura, który przede wszystkim podziękował tym, którzy przyczynili się do szerzenia „oświaty pomiędzy ludzi upadłych"56, kierownikowi szkoły Edwardowi Gabryjelskiemu i trzem innym nauczycielom: Mazurkiewiczowi, Karasińskiemu i dyrektorowi Janowi Szubowiczowi. Na zakończenie zwrócił się również do uczniów, opisując "dobrodzieja i dobrodziejstwo szkoły" ${ }^{2}$. Jako ostatni głos zabrał prezydent Zawadzki, który powiedział: „Zawsze twierdziłem i twierdzę, że człowiek nie rodzi się zbrodniarzem, że na ten upadek człowieka wpływają - otoczenie, brak oświaty i stosunki majątkowe"58.

W związku z tym artykułem kierownik E. Gabryjelski przesłał do następnego numeru „Orła” krótkie pismo wyjaśniające, że w recenzji odnoszącej się do szkoły więźniów pominięto zasługi jednego z nauczycieli, Jana Styły.

Nauczyciel ten udzielając początków czytania i pisania, spełnia najtrudniejsze właśnie zadanie szkoły, a zawiadując nadto biblioteką, dźwiga niemałe brzemię dobrowolnie na się przyjętych obowiązków. Że zaś z zadania swego i obowiązków swych wywiązuje się równie gorliwie i sumiennie, jak wszyscy inni nauczyciele, dowodem na to słowa zapisane w księdze lustracyjnej przez c. k. Inspektora szkół, p. Fr. Haburę, które tutaj dosłownie przytaczam: „Szczęść Boże! Oby w tej książce zapisywano zawsze tylko takie uwagi, do jakich dał powód dnia dzisiejszego odbyty egzamin w szkole więźniów. Święciła tu cnota swe tryumfy. Miłość podawała rękę grzesznikowi, światło ciemnocie. Poświęcenie J. W. Pana Ryszarda Zawadzkiego, nie szczędzącego pracy i zabiegów, aby szkółce zabezpieczyć pomyślny rozwój; gorliwa i pełna poświęcenia praca nauczycieli: pp. Edwarda Gabryelskiego, kierownika, Wul Tarsińskiego, Al. Mazurkiewicza i Jana Styły, a nadto ojcowska troskliwość Zarządcy więzienia, Romana Pindelskiego, wydały świetne owoce: 53 uczniów pobierało naukę języka polskiego, pisania, rachunków, geografii z historią i stylistyki z zadziwiającym skutkiem"59.

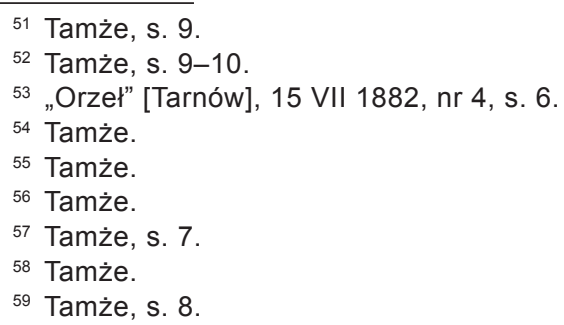


Kolejny tekst autorstwa E. Gabryjelskiego, Przyczynek do historii szkół po c. k. domach karnych i więzieniach, znalazł się w 6. numerze „Orła”. Dotyczył tarnowskiej szkoły więźniów, która w każdym roku kształciła od 50 do 60 skazanych. W 1882 r. przeżywała poważne problemy, była bliska zamknięcia. Od założenia w 1869 do 1876 r. zawdzięczała swoje funkcjonowanie ofiarności kilku nauczycieli, pracujących bezinteresownie. Dzięki staraniom prezydenta sądu Ryszarda Zawadzkiego Ministerstwo Sprawiedliwości przeznaczyło na utrzymanie czterech nauczycieli tego zakładu po 40 zł rocznie stałego wynagrodzenia.

Gdy jednak ciężar tej pracy w więzieniu z jednej, a materialne położenie dotyczących nauczycieli z drugiej strony zmusiły ich do wyjawienia zamiaru zaniechania dalszych ofiar z sił i czasu swojego podniosło tęż płacę Wys. c. k. Minist. spraw. [...] do podwójnej wysokości, przyznając nadto 25 zł rocznie za kierowanie Zakładem. Również podniosło [...] niedostateczne pauszale na przybory naukowe tej szkoły z 15 na 25 zł rocznie, czym jej byt ustaliło na zawsze. [...] i na sprawienie sprzętów szkolnych nie szczędziło i nie szczędzi kosztów; [...] instytucji tej w 2 tylko latach ostatnich 96 książek naukowych bezpłatnie przesłało $[\ldots]^{60}$.

Publicyści „Orła” informowali na bieżąco o decyzjach Rady Szkolnej Krajowej, np. o mianowaniu rzeczywistego nauczyciela młodszego Henryka Mendochy rzeczywistym nauczycielem starszym, a tymczasowego nauczyciela Jana Ciejki rzeczywistym nauczycielem młodszym w szkole wydziałowej męskiej ${ }^{61}$. Na łamach pisma publikowano także ogłoszenia dotyczące m.in. naboru do szkół. Informowano np. o tym, że od 1 września 1882 r. do szkoły sadowniczo-ogrodniczej w Tarnowie ${ }^{62}$ zostanie przyjętych dziesięciu uczniów, których utrzymanie (czyli koszty wyżywienia, mieszkania, zakupu mundurków świątecznych i codziennych) pokryje szkoła. Natomiast nowo przyjęci sami będą opłacać część kosztów utrzymania od 5 do 10 zł miesięcznie, powinni mieć również własne ubranie do pracy oraz książki do nauki. Uczniów można zgłaszać ustnie, codziennie między 8.00 a 10.00 rano oraz pisemnie pod adresem dyrekcji szkoły, dołączając do podania świadectwa: urodzenia, szkolne z ukończonej „szkoły pospolitej jakiejkolwiek kategorii” ${ }^{3}$ oraz „deklarację przez dwóch świadków podpisaną, że rodzice lub opiekunowie opłacać będą od ucznia przez 4 lata nauki po 5-10 zł miesięcznie ratami antycypacyjnemi" 64 . Nauka w szkole sadowniczo-ogrodniczej obejmowała dwa półrocza: zimowe (nauka przedmiotów z zakresu wyższych szkół ludowych) oraz letnie (zajęcia praktyczne). Ponadto w pierwszym roku nauki uczniowie mieli wykonywać najprostsze czynności z zakresu ogrodnictwa ${ }^{65}$. Po zakończeniu czterech lat edukacji dodatkowo kierowani byli na dwa lata do pracy w większych ogrodach jako subiekci, aby zdobyć większe doświadczenie, następnie przystępowali do egzaminu kwalifikacyjnego, a dopiero potem starali się o pracę ${ }^{66}$.

\footnotetext{
60 „Orzeł” [Tarnów], 15 VIII 1882, nr 6, s. 6.

61 Tamże, s. 5.

62 Tamże, s. 6.

63 Tamże.

64 Tamże.

65 Plewienie, gracowanie, zamiatanie deptaków w ogrodzie miejskim, wożenie taczkami, kopanie, grabienie.

66 Tamże.
} 
Informowano, że w niedzielę 29 października 1882 r. ${ }^{67}$ odbyło się spotkanie, podczas którego postanowiono utworzyć Stowarzyszenie Opieki dla Młodzieży Szkolnej, wspierające ubogą młodzież szkolną ${ }^{68}$. F. Habura, przewodniczący, rozpoczął posiedzenie, a następnie sekretarz E. Gabryjelski odczytał sprawozdanie z działalności komitetu opiekującego się ubogą młodzieżą tarnowskich szkół ludowych od 25 października 1879 do 29 października 1882 r. (od chwili powstania do rozwiązania i przekształcenia w Stowarzyszenie). „Orzeł” opublikował również sprawozdanie z trzyletniej działalności, odczytane w trakcie Walnego Zgromadzenia ${ }^{69}$.

Teksty prasowe, zamieszczone w tarnowskim czasopiśmie „Orzel” z $1882 \mathrm{r}$. zwracają uwagę różnorodnością tematyki dotyczącej oświaty i szkolnictwa. $\mathrm{Na}$ łamach pisma informowano o wielu wydarzeniach z życia szkół i stowarzyszeń oświatowych, działających w Tarnowie, o inicjatywach obywateli mających pomóc szerzeniu oświaty oraz decyzjach władz szkolnych. Przekazywano również wiadomości z kraju i ze świata, związane z edukacją (np. młodzież polska na zagranicznych uniwersytetach, zjazdy towarzystw oświatowych poza Tarnowem). Mimo że pismo nie miało charakteru edukacyjnego (był to periodyk o charakterze społeczno-ekonomicznym), to jednak sprawom szkolnictwa i oświaty poświęcano na jego łamach wiele uwagi. $Z$ tego względu tarnowskie czasopismo "Orzel” należy uznać za niezwykle interesujące źródło w badaniach dziejów edukacji lokalnej i narodowej.

67 „Orzeł” [Tarnów], 1 XI 1882, nr 11, s. 4.

${ }^{68} \mathrm{~W}$ tym samym czasie obradował Komitet Opieki nad Żebrakami, a to miało wpływ na mniejszą frekwencję. Tamże.

69 Tamże. 